\title{
Relation between fatty acids' chemical profile and chemotaxonomy of Czech barley (Hordeum vulgare) varieties, their geographical origin and malting process
}

\author{
Jana Olšovskái* ${ }^{*}$, Tomáš Vrzal ${ }^{1}$, Karel Štěrba ${ }^{1}$, Pavel Čejka ${ }^{1}$, Tomáš Horák ${ }^{1}$, Alexandr Mikyška ${ }^{1}$ \\ ${ }^{1}$ Research Institute of Brewing and Malting, PLC, Lípová 15, \\ CZ - 12044 Prague, Czech Republic ～～*corresponding author: olsovska@beerresearch.cz
}

\begin{abstract}
The dependence of FA profiles in barley and malt on variety and geographical origin was determined using an optimized method. FA profiles from 6 Czech varieties, each from 5 localities, during two crop years were studied. Extraction of lipids and FA with hexane by fluidized bed extraction and hydrolysis of lipids prior to derivatization of FA was used. The statistical processing of FA profiles led to a differentiation of samples; the importance of distinguishing parameters decreases in the order of crop year $>$ geographical origin $>$ variety. Nevertheless, the differentiation of tested varieties using FA profiles coresponds to a varietal pedigree. A statistical difference in terms of the total lipid content was found between two varieties (Malz and Sunshine) and two tested localities. The profile of FA in barley grains is influenced by the land type and climate conditions. Due to a high level of barley varieties crossbreeding, the chemical profiling of FA is not a reliable tool for a varietal determination, however, it reflects the variety origin.
\end{abstract}

Key words: barley (Hordeum vulgare), fatty acids profiling, chemotaxonomy, varietal dependence, geographical origin

\section{Introduction}

Barley (Hordeum vulgare) is used as feed, for a preparation of various cereal food products, for ethanol production, and especially for malt and the following beer production. Grains of various barley varieties differ in the amount of many chemical compounds, which affects the nutrient composition, technological parameters and sensory properties of the final product. Therefore, an appropriate variety of barley has to be used for the production of a specific product. The varietal specificity can be determined by various methods (Analytica EBC, 2012; García-Villalba et al., 2006; Řehulka et al., 2006; Laštovičková et al., 2012).

Further, some studies were published that use a chemical profile of fatty acids (FA) for differentiation of barley varieties. FA are important metabolic products of living organisms including bacteria, yeasts, fungi, insects, fish, mammals and also plants (Brondz et al., 2002). The FA profiles processed by a multivariate statistical anal- ysis, namely, the principal component analysis (PCA), the partial least squares discriminant analysis and the soft-independent modelling of class analogy, are used in chemotaxonomic studies. This approach is very successful and effective for the classification of microbial strains (Brondz et al., 2002), yeasts (Bronds et al., 1990), marine organisms such as microalgae (Sahu et al., 2013) or fungi (Aliferis et al., 2013). Moreover, up-to-date studies of the chemometric classification of different plant species are also available; for example, FA were used as chemotaxonomic markers for Tree Peony (Zhang et al., 2017), Paracaryum (Dogru-Koca et al., 2016), Velella velella (Linnaeus) and Physalia physalis (Linnaeus) (Lopes et al., 2016).

Armanino et al. studied the differences between unsaturated FA with 18-carbon atoms (C18), sterol fraction and the other components in order to differentiate between Triticum durum from T. aestivum, used for "pasta" 
and bread making, respectively. They used the classification methods of linear discriminant analysis and quadratic discriminant analysis for the purpose of differentiating wheat species, origins, varieties and crops. They found that the only marker able to distinguish between the two species is oleate, with a prediction rate of $100 \%$. Inside the species T. durum, a prediction rate of $83.9 \%$ was obtained when discriminating between the different origins. The prediction rate of $82.2 \%$ was obtained when discriminating among varieties and a prediction rate of $94.3 \%$ for distinguishing between crop years (Armanino et al., 2002).

Liu studied a FA distribution across a grain seed, namely barley, oat, rice, sorghum, and wheat, each with two genotypes. After pearling of the seeds, they surveyed a lipid content and the FA composition. Compared to barley and wheat, rice, oat and sorghum had a higher relative percentage of C18:1 (31.60 to 36.64\% compared to 12.15 to $15.61 \%$ ) and a lower content of C18:2 (35.69 to $45.44 \%$ compared to 50.79 to $61.50 \%$ ). For all 10 grains, from the seed surface to inner core, C16:0 and C18:0 increased, C18:1 and C18:3 decreased, and C18:2 changed slightly, providing a new reason for improved oxidative stability for pearled kernels. The differences in changing intensity of FA composition among grain species correspond to those in oil distribution in the seed, while a varietal difference in distribution patterns and the FA composition of lipids within the species were insignificant (Liu, 2011).

Pastor et al. identified lipid components and soluble sugars in flour samples of 8 different cultivars of barley, involving winter malting barley, winter forage barley, spring barley, and hulless barley. Consequently, they applied the multivariate analysis to the numerical values of peak areas of the identified FA methyl esters and derivatized sugars. The application of hierarchical cluster analysis proved a high degree of correlation similarity among the investigated flour samples of the barley cultivars, according to their FA and soluble sugar content. They concluded that there is a possibility of distinguishing flours made from barley, though not reaching to particular barley varieties, just by the analysis of the contents of FA and soluble sugars (Pastor et al., 2015).

On the contrary, Gangopadhyay et al. found some correlation between the barley varieties and chemical profiling. They determined and compared three types of lipophilic phytochemicals, FA, phytosterols and tocols, in five whole grain Irish barley varieties. The PCA revealed interesting correlations between these phytochemicals. An evident relationship between the unsaturated FA and some tocol homologues was observed. Sterols like $\beta$-sitosterol and $\beta$-sitostanol were negatively correlated with each other. The PCA also indicated possible genotypic relationships among the barley varieties (Gangopadhyay et al., 2017).
Bravi et al. investigated not only varietal similarities in the FA profiles, but mainly the influence of the barley variety and the malting process on the lipid content of finished malt. They used five barley samples grown in Italy, representing 4 spring varieties and 1 winter variety; PCA was used to establish the relationships between the different samples. The different barley varieties presented different FA contents and different FA patterns. The authors did not find any varietal specificity in the FA profile, but the correlation between the lipid content of barley and the quality of the resulting malt confirmed a negative influence of lipids (Bravi et al., 2012).

Due to discrepancies and incompleteness of published results, we decided to re-evaluate and unify the relationship between the FA profiles and the barley varieties, and the geographical origin. In addition, the studies mentioned above are in most cases based on a low number of samples which could be insufficient for a relevant statistical evaluation. We therefore studied 6 Czech varieties (Bojos, Francin, Kangoo, Laudis 550, Malz, Sunshine), each from 5 localities during two crop years (2014 and 2015). Moreover, we improved the method of the FA determination, so we were able to determine not only free FA but also FA bound in lipids. Finally, the results were processed by the PCA and the analysis of variance (ANOVA).

\section{MATERIALS AND METHODS}

\subsection{Chemicals}

Standard of FA Supelco 37 component FAME mix and internal standard of tridecanoic acid (99\%) were purchased from Sigma Aldrich (Czech Republic). For concentration and retention time see Table 1.

Other chemicals were hexane (99\%, Merck, Germany), ethanol (analytical grade, Lachner, Czech Republic), methanol (99.9\% Merck, Germany), boron trifluoride-methanol solution $10 \%$ in methanol (w/w, Sigma Aldrich, Czech Republic), potassium hydroxide (Lachner, p.a., Czech Republic) and sodium hydrogensulphate (Lachner, p.a., Czech Republic). Ultrapure water was prepared by MilliQ (Millipore, USA).

\subsection{Samples}

Grain of six spring malting barley varieties Bojos, Francin, Kangoo, Laudis 550, Malz, Sunshine, grown in the Czech Republic on the test sites Hrubčice (HE), Staňkov (STV), Jaroměřice nad Rokytnou (JAR), Krásné Údolí (KUD) and Uherský Ostroh (UHO) using the same farming techniques in 2014 and 2015, were used for the experiment. The lipid content and FA analysis were performed in barley grain and related malt. 
Table 1 Methyl esters of FA in Supelco 37 component FAME mix, concentrations and retention time

\begin{tabular}{|c|c|c|}
\hline Analyte & Concentration ( $\left.\mu \mathrm{g} \mathrm{L}^{-1}\right)$ & Retention time (min) \\
\hline Methyl Butyrate & 399.7 & $<1^{*}$ \\
\hline Methyl Hexanoate & 399.5 & 1.05 \\
\hline Methyl Octanoate & 399.5 & 1.26 \\
\hline Methyl Decanoate & 399.6 & 1.71 \\
\hline Methyl Undecanoate & 199.9 & 2.00 \\
\hline Methyl Laurate & 399.7 & 2.33 \\
\hline Methyl Tridecanoate (IS) & 197.4 & 2.68 \\
\hline Methyl Myristate & 399.6 & 3.02 \\
\hline Myristoleic Acid Methyl Ester & 199.9 & 3.15 \\
\hline Methyl Pentadecanoate & 199.8 & 3.37 \\
\hline Cis-10-Pentadecanoic Acid Methyl Ester & 198.0 & 3.50 \\
\hline Methyl Palmitate & 599.4 & 3.73 \\
\hline Methyl Palmitoleate & 199.9 & 3.78 \\
\hline Methyl Heptadecanoate & 199.2 & 4.03 \\
\hline Cis-10-Heptadecanoic Acid Methyl Ester & 196.9 & 4.11 \\
\hline Methyl Stearate & 399.6 & 4.35 \\
\hline Trans-9-Elaidic Methyl Ester & 199.4 & $4.43^{* *}$ \\
\hline Cis-9-Oleic Acid Methyl Ester & 399.7 & $4.43^{* *}$ \\
\hline Linolelaidic Acid Methyl Ester & 199.7 & $4.58^{* *}$ \\
\hline Methyl Linoleate & 199.9 & $4.58^{* *}$ \\
\hline Gamma-Linolenic Acid Methyl Ester & 199.8 & 4.65 \\
\hline Methyl Linolenate & 199.8 & 4.77 \\
\hline Methyl Arachidate & 399.7 & 4.98 \\
\hline Methyl cis-11-Eicosanoate & 199.9 & 5.05 \\
\hline Cis-11,14-Eicosadienoic Acid Methyl Ester & 199.8 & 5.26 \\
\hline Cis-8,11,14-Eicosatrienoic Acid ME & 199.6 & 5.37 \\
\hline Methyl Heneicosanoate & 199.8 & 5.40 \\
\hline Cis-11,14,17-Eicosatrienoic Acid ME & 199.8 & 5.50 \\
\hline Methyl Cis-5,8,11,14-Eicosatetraenoate & 197.3 & 5.55 \\
\hline Methyl Behenate & 398.9 & $5.83^{* *}$ \\
\hline Methyl Cis-5,8,11,14,17-Eicosapentaenoate & 199.5 & $5.83^{* *}$ \\
\hline Methyl Erucate & 199.8 & 5.96 \\
\hline Cis-13,16-Docosadienoic Acid ME & 199.8 & 6.25 \\
\hline Methyl Tricosanoate & 199.8 & 6.39 \\
\hline Methyl Lignocerate & 399.6 & 7.09 \\
\hline Cis-4,7,10,13,16,19-Docosahexaenoic Acid ME & 199.9 & 7.30 \\
\hline Methyl Nervonate & 199.8 & 7.38 \\
\hline
\end{tabular}

* a methyl butyrate peak coelutes with a solvent peak and was, therefore, not determined

** analytes with the same retention time were determined as the sum of these analytes

\subsection{Malting}

The pilsner malts were prepared in our micromalting plant according to MEBAK methodology (MEBAK, 2011). Steeping of grain was performed with $\mathrm{CO} 2$ exhaustion; duration of steeping periods was the following: 1st day - 5 hours, 2 nd day -4 hours and 3 rd day -3 hours. Total steeping and germination time was 6 days, germination temperature was $14^{\circ} \mathrm{C}$. The predrying step was carried out for 12 hours at $55{ }^{\circ} \mathrm{C}$, the kilning step for 4 hours at $80^{\circ} \mathrm{C}$.

\subsection{Sample preparation}

Firstly, lipids were extracted from the grain as follows. Five grams of finely ground sample was extracted by 
$60 \mathrm{~mL}$ of hexane by Fluidized-Bed Extraction (FBE) using FexIka extractor (IKA Labortechnik, Germany). The number of cycles was 6 (approx. $120 \mathrm{~min}$ ), the temperature of heating block was $102{ }^{\circ} \mathrm{C}$ and the cooling temperature was $40{ }^{\circ} \mathrm{C}$. The hexane extract was then evaporated in the rotary evaporator Hei-VAP (Heidolph, Germany) until only one drop was left, and then it was dried for 2 hours at $105^{\circ} \mathrm{C}$. The resulting oil drop was weighed and the absolute amount of lipid in grain was obtained.

The extracted lipids were then derivatized as follows. Firstly, the whole lipid extract was dissolved in $2 \mathrm{~mL}$ of hexane and $100 \mu \mathrm{L}$ of this solution was derivatized. Then, 10 $\mu \mathrm{L}$ of tridecanoic acid (IS $-0.05 \mathrm{~g}$ in $25 \mathrm{~mL}$ of ethanol) was added to the sample and the mixture was dried under the flow of nitrogen to dryness. After the addition of $0.5 \mathrm{~mol}$ $\mathrm{L}^{-1}$ methanolic $\mathrm{KOH}(0.1 \mathrm{~mL})$, the sample was heated for $30 \mathrm{~min}$ at 85 ${ }^{\circ} \mathrm{C}$. It was then cooled, $0.1 \mathrm{~g}$ of sodium hydrogensulphate was added and the sample was thoroughly mixed. $\mathrm{BF}_{3}$-methanol volume of $0.1 \mathrm{~mL}$ was added and the sample was heated for $60 \mathrm{~min}$ at $85^{\circ} \mathrm{C}$. Two hundred microliters of water was added and FA methyl esters were extracted by $0.2 \mathrm{~mL}$ of hexane. The hexane so prepared extract was injected on the GC column.

\subsection{GC measurement}

The FA methyl esters were determined on the gas chromatograph Chrompack CP 9001 with a split/splitless injector, DB-WAX $20 \mathrm{~m} \times 0.18 \mathrm{~mm} \times 0.18 \mu \mathrm{m}$ column, and a flame-ionization detector. The gas chromatograph was equipped with a Labio ASG 40 autosampler. The chromatographic column was maintained at $120^{\circ} \mathrm{C}$ and after the injection of $1 \mu \mathrm{L}$ of the sample this temperature was kept for $0.7 \mathrm{~min}$. Then the column oven was ramped at a step of $30^{\circ} \mathrm{C} \mathrm{min}^{-1}$ to $240{ }^{\circ} \mathrm{C}$, and held isothermally for $7 \mathrm{~min}$. The split injection mode with a split ratio 1:10 was used. The injector temperature was $250^{\circ} \mathrm{C}$ and the detector temperature was $220^{\circ} \mathrm{C}$. The carrier gas was helium (5.0) with a column head pressure of $200 \mathrm{kPa}$. It is recommended to inject pure hexane between real samples to avoid false results due to a possible carry-over. Since some FA peaks co-eluted under these conditions, they were evaluated as a sum of co-eluting FA (see Table 1). Quantification of FA concentration was performed using one-point calibration.

\subsection{Data processing}

Statistical analysis, data treatment and graphs were performed using Statistica 12. ANOVA was used to determine the effect of the barley variety and geographical origin on FA. FA concentrations with a non-symmetrical distribution were transformed by the Johnson transformation to a normal distribution $(\alpha=0.05)$. PCA was used to evaluate a possible clustering of samples by the barley variety and/or by the location.

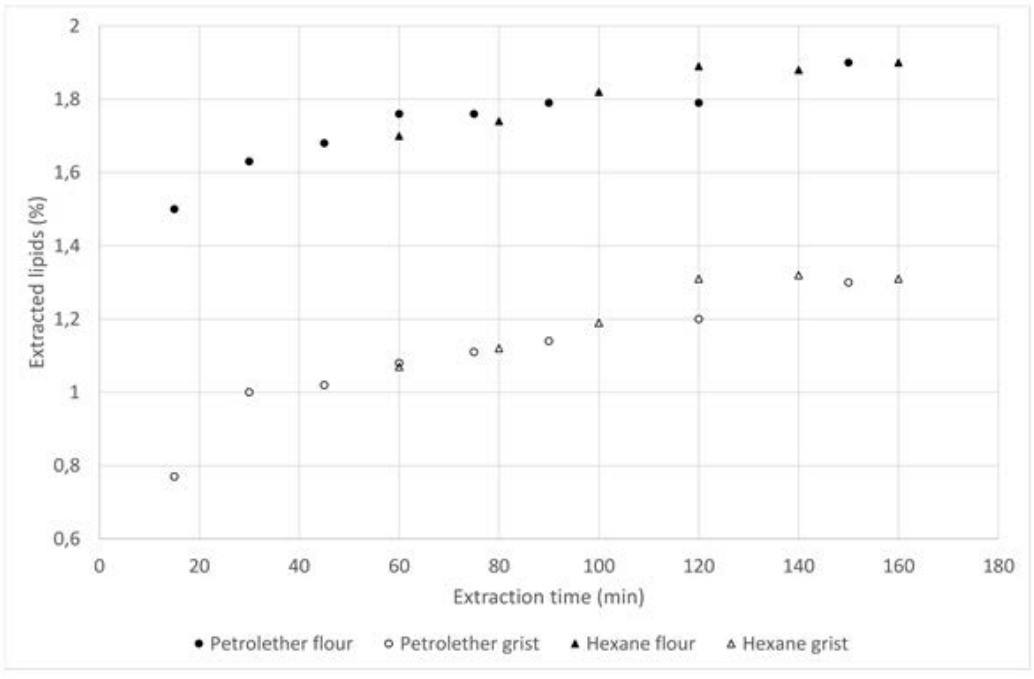

Figure 1 Dependence of the amount of extracted lipids on the time of the extraction

\section{RESULTS AND DISCUSSION}

\subsection{Extraction process}

The extraction on FBE was based on the publication of Svoboda et al. (Svoboda et al., 2009). However, we exchanged petroleum ether for hexane and compared the efficiency of the two solvents. When hexane and petroleum ether were used, the respective temperature of a heating block during the extraction procedure was $102{ }^{\circ} \mathrm{C}$ and $72{ }^{\circ} \mathrm{C}$. Figure 1 shows the amount of lipid extracted from the sample of barley flour and grist. The difference between the flour and the grist was found to be too big and it is better to use a finely milled sample for the lipid extraction. Further, it was observed that more extraction cycles (i.e. heating of solvent, boiling time and cooling of solvent) are needed when usng petroleum ether for comparable recovery than when hexane is used; on the other hand, the cycles with petroleum ether take less time than with hexane, so the comparison of the extracted amount of lipids in time led to similar results. Due to lower evaporation of hexane during the extraction process and its easier handling, we decided to use hexane within the experiment. 


\subsection{The derivatization process}

The sample was derivatized using a 1-hour incubation at $85{ }^{\circ} \mathrm{C}$ with the $\mathrm{BF}_{3}$-methanol solution. Because only some FA can be released from the lipids when using the derivatization with the $\mathrm{BF}_{3}$-methanol solution, we tested an addition of $0.1 \mathrm{~mol} \mathrm{~L}^{-1}$ methanolic $\mathrm{KOH}$ and $30 \mathrm{~min}$ incubation at $85{ }^{\circ} \mathrm{C}$ before $\mathrm{BF}_{3}$ derivatization. When the step with the methanolic $\mathrm{KOH}$ hydrolysis was used, the amount of the majority of FA showed no statistically significant differences (data not shown) but some concentrations of FA increased significantly (see Table 2). The concentration growth ranged from approximately twofold for cis-10-pentadecenoic acid to more than ten-fold for both cis-11,14-eicosadienoic acid and cis-8,11,14-eicosatrienoic acid.

\subsection{Total lipid content}

The total lipid content in barley grain measured using FBE ranged from 16.4 to $20.0 \mathrm{~g} \mathrm{~kg}^{-1}$ (dry matter, data not shown). It corresponds with the results of Bravi et al. using the Soxhlet extraction according to which the total lipid content ranged from 17.8 to $21.0 \mathrm{~g} \mathrm{~kg}^{-1}$ (dry matter) (Bravi et al., 2012). Due to the similarities of lipid content, it could be assumed that both extraction techniques are comparable.

Based on the total lipid content, Bravi et al. differentiated samples of both barley and malt into two clusters with significant differences (Bravi et al., 2012). We were not able to distinguish our samples so unambiguously. The only statistical difference was found between the varieties Malz and Sunshine, where the median of lipids amount was 19.1 and $16.9 \mathrm{~g} \mathrm{~kg}^{-1}(\mathrm{p}=0.026)$. Also, a significant difference between two localities, $\mathrm{HE}$ and $\mathrm{UH}$, was found, where the total lipid content was 17.2 and $19.3 \mathrm{~g} \mathrm{~kg}^{-1}(\mathrm{p}=0.005)$, respectively.

Interestingly enough, Anness found higher concentration of total lipids in barley, namely 34-44 $\mathrm{g} \mathrm{kg}^{-1}$, when measured as total FA (Anness, 1984). Unlike other authors, he used for the sample preparation hydrolysis with $6 \mathrm{M} \mathrm{HCl}$ at $60{ }^{\circ} \mathrm{C}$ for $1 \mathrm{~h}$, with chloroform extraction and GC-FID analysis. He found that even when using acidic hydrolysis, FA from phospholipids and glycolipids still remain bonded, and, therefore, the real amount of FA would be higher.

\subsection{FA profiling in barley}

A summary of fatty acid concentrations across all studied barley varieties is given in Table 3 , which gives the median, 1st and 3rd quartile and inter quartile range. In accordance with the studies of Gangopadhyay et al. and Bravi et al., we also found a relationship between the barley varieties and the FA profile (Gangopadhyay et al., 2017; Bravi et al., 2012). The influence of a crop year and a growing locality on the FA profile were also observed.
The importance of these parameters decreases in the order crop year $>$ geographical origin $>$ variety. Figure 2 demonstrates that the strongest influence is exerted by the crop year. Based on PCA, the barley samples were divided into two well separated clusters containing samples from 2014 and 2015.

Subsequently, the lauric, arachidonic, pentadecanoic, palmitoleic and myristic acids were selected as FA dependent on the variety and the geographical origin using ANOVA. We find it interesting that we found myristic acid varietally and locally dependent, 27.3 to $76.7 \mathrm{mg} \mathrm{kg}^{-1}$, while Anness (1984) found myristic acid in only a negligible concentration.

The dependence of the geographical origin, which has a less tight correlation with the FA profile in comparison with the crop year, is shown in Figure 3. Table 4 specifies the chacteristics of five growing localities where our samples were produced, including production region, altitude, temperature, rainfall, and the type of soil. After processing these data using PCA, we obtained a cluster of samples from the localities UHO and partially also from HE, which are separated from the other localities. UHO and HE localities are characteristic by a similar low altitudes, 196 and $210 \mathrm{~m}$, respectively, and by the highest average temperature per year, 8.5 and $9.1^{\circ} \mathrm{C}$, respectively. It should also be mentioned that the UHO and HE localities are approx. $55 \mathrm{~km}$ apart, the other localities being further away (100 $\mathrm{km}$ and more).

Next, the varietal specificity was evaluated. It is worth noting that malting barley varieties are bred with respect to the basic parameters of malting quality such as starch and protein content, beta-glucan content and the activity of important hydrolytic enzymes controlling cytolytic, saccharolytic and proteolytic modification of the grain. The lifetime of contemporary intensive varieties of barley and other cereals in the field is relatively short. These varieties get old rapidly, losing yields and disease resistance. The proven varieties and other breeding material are used for crossbreeding new genotypes. It is very likely that in addition to the basic malting characteristics the current varieties are similar in other characters. The mutual relationship of the tested varieties appeared in the results demonstrated in Figure 4. After PCA, the samples of varieties Kango (Psota et al., 2008) and Sunshine (Psota, et al., 2012), which are relatives with Braemer as the common ancestor, were clustered to neighboring groups (see Figure 5). Similarly, Francin (Psota et al., 2014) and Laudis 550 (Psota et al., 2013), which are relatives of Sebastian as the common ancestor, created also close clusters. The cluster of Bojos (Psota et al., 2005), which is the ancestor of Laudis 550, overlaps with the cluster of Laudis 550. These findings are in accordance with the known pedigree of tested varieties. 
Table 2 A description of tested geographical origin

\begin{tabular}{|c|c|c|}
\hline FA & Concentration without KOH $\left(\mathrm{mg} \mathrm{kg}^{-1}\right)$ & $\begin{array}{c}\text { Concentration with KOH treatment } \\
\left(\mathrm{mg} \mathrm{kg}^{-1}\right)\end{array}$ \\
\hline cis-10-pentadecenoic acid & $6.2 \pm 1.7$ & $13.3 \pm 1.7$ \\
\hline cis-11,14-eicosadienoic acid & $0.70 \pm 0.14$ & $8.8 \pm 1.8$ \\
\hline cis-8,11,14-eicosatrienoic acid & $0.10 \pm 0.02$ & $2.3 \pm 0.3$ \\
\hline arachidonic acid & $0.30 \pm 0.17$ & $1.0 \pm 0.5$ \\
\hline cis-5,8,11,14,17 & $34.1 \pm 10.4$ & $78.9 \pm 13.4$ \\
\hline -eicosapentaenoic + behenic acid & & \\
\hline
\end{tabular}

Table 3 Summary of fatty acids across all studied barely varieties

\begin{tabular}{|c|c|c|c|c|}
\hline Fatty acid & Median & 1st Quartile & 3rd Quartile & $\mathrm{IQR}^{*}$ \\
\hline Caproic & 0.62 & 0.17 & 2.64 & 2.47 \\
\hline Caprylic & 0.53 & 0.40 & 0.91 & 0.51 \\
\hline Capric & 0.70 & 0.56 & 1.13 & 0.56 \\
\hline Undecanoic & 0.12 & 0.06 & 0.19 & 0.12 \\
\hline Lauric & 2.03 & 1.78 & 2.37 & 0.59 \\
\hline Myristic & 40.26 & 33.27 & 53.38 & 20.11 \\
\hline Myristoleic & 0.52 & 0.29 & 1.10 & 0.81 \\
\hline Pentadecanoic & 11.01 & 9.62 & 12.63 & 3.00 \\
\hline cis-10-pentadecenoic & 1.26 & 0.33 & 2.95 & 2.62 \\
\hline Palmitic & 2571.24 & 2062.05 & 2935.13 & 873.08 \\
\hline Palmitoleic & 11.44 & 10.25 & 13.35 & 3.10 \\
\hline heptadecanoic & 8.01 & 6.04 & 9.85 & 3.81 \\
\hline cis-10-heptadecenoic & 3.62 & 2.95 & 4.57 & 1.62 \\
\hline Stearic & 158.97 & 104.33 & 213.35 & 109.02 \\
\hline Oleic+Elaidic & 1709.78 & 1133.55 & 2200.86 & 1067.32 \\
\hline Linoleic+linolelaidic & 6857.44 & 5167.44 & 8432.04 & 3264.60 \\
\hline gama-linolenic & 0.52 & 0.35 & 0.71 & 0.36 \\
\hline alfa-linolenic & 580.35 & 456.23 & 766.35 & 310.12 \\
\hline Arachidic & 28.59 & 19.13 & 41.67 & 22.54 \\
\hline cis-11-eicosenoic & 101.10 & 63.13 & 148.41 & 85.28 \\
\hline cis-11.14-eicosadienoic & 8.83 & 6.21 & 11.16 & 4.95 \\
\hline cis-8.11.14-eicosatrienoic & 2.31 & 1.12 & 3.10 & 1.99 \\
\hline Heneicosanoic & 0.04 & 0.02 & 0.11 & 0.09 \\
\hline cis-11.14.17-eicosatrienoic & 0.41 & 0.09 & 0.80 & 0.71 \\
\hline Arachidonic & 0.41 & 0.20 & 0.83 & 0.62 \\
\hline cis-5.8.11.14.17-eicosapentaenoic+behenic & 27.41 & 13.51 & 39.70 & 26.19 \\
\hline Eruic & 22.80 & 12.43 & 32.96 & 20.53 \\
\hline cis-13.16-docosadienoic & 0.76 & 0.39 & 1.76 & 1.37 \\
\hline Tricosanoic & 4.91 & 3.53 & 6.88 & 3.35 \\
\hline Lignoceric & 16.82 & 9.97 & 27.88 & 17.91 \\
\hline cis-4.7.10.13.16.19-docosahexaenoic & 11.39 & 6.83 & 14.76 & 7.92 \\
\hline Nervonic & 1.37 & 0.42 & 3.01 & 2.59 \\
\hline sum of saturated FA & 2946.83 & 2261.16 & 3379.35 & 1118.19 \\
\hline sum of unsaturated FA & 9176.96 & 6735.28 & 11414.55 & 4679.26 \\
\hline sum of polyunsaturated FA & 6897.91 & 5204.30 & 8467.58 & 3263.28 \\
\hline sum of FA & 12219.01 & 8960.98 & 14853.18 & 5892.20 \\
\hline
\end{tabular}


Table 4 Differences of selected FA with or without methanolic KOH treatment

\begin{tabular}{|c|c|c|c|c|c|c|}
\hline Location name & Location code & $\begin{array}{c}\text { [Production } \\
\text { region] }\end{array}$ & [Altitude $(\mathrm{m})]$ & $\begin{array}{c}\text { Temperature } \\
\text { average }\left({ }^{\circ} \mathrm{C}\right)\end{array}$ & $\begin{array}{c}\text { Rainfall aver- } \\
\text { age }(\mathrm{mm})\end{array}$ & Code of soi** $^{* *}$ \\
\hline Krásné Údolí & KUD & 4 & 647 & 6.3 & 602 & $\mathrm{~A}$ \\
\hline Jaroměřice nad Rokytnou & JAR & 3 & 425 & 8.0 & 481 & $\mathrm{~B}$ \\
\hline Staňkov & STV & 3 & 370 & 8.1 & 537 & $\mathrm{C}$ \\
\hline Uherský Ostroh & UHO & 1 & 196 & 9.1 & 521 & $\mathrm{D}$ \\
\hline Hrubčice & HE & 2 & 210 & 8.5 & 578 & $\mathrm{E}$ \\
\hline
\end{tabular}

*1- maize production region, 2 - sugar beet production region, 3 - cereal production region, 4 - forage production region

${ }^{* *}$ A - Eutric Cambisol (Loamy sand - light), B - Orthic Luvisol (Clayey-loam - heavy), C - Orthic Luvisol (Loamy soil - medium), $D$ - Eutric Cambisol (Loamy soil - medium), E - Luvi-haplic Chernozem (Loamy soil - medium).

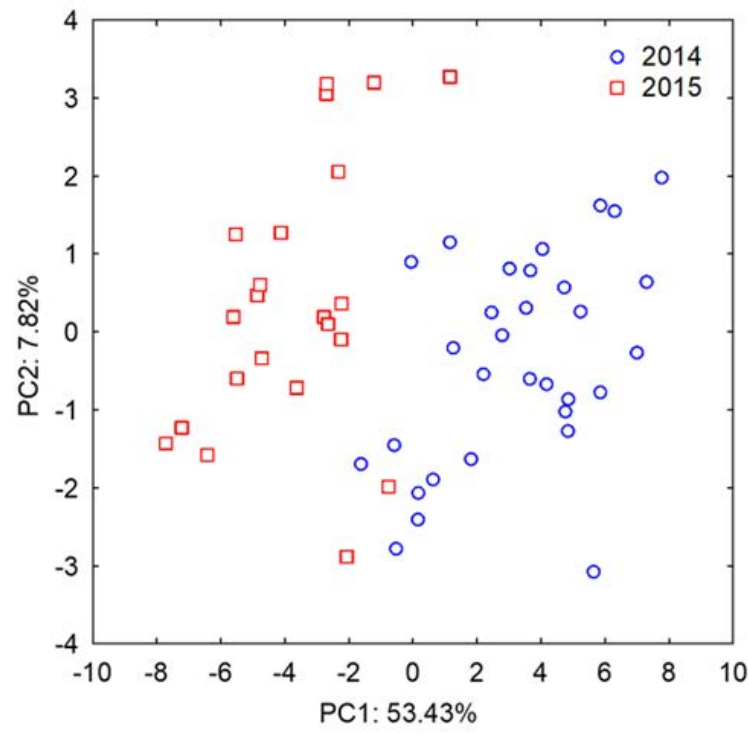

Figure 2 Principal component analysis. The influence of crop year on the FA profile
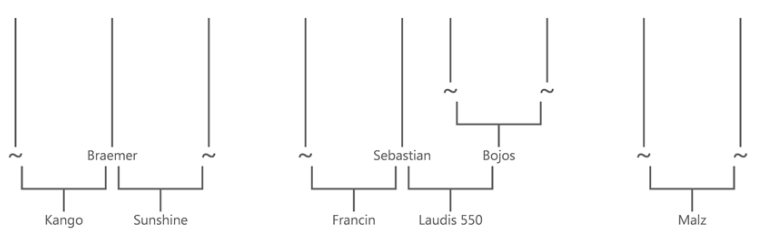

Figure 4 Multidimensional description of differences in FA composition of barley grains among growing locations based on PLS-DA.

Legend: Kangoo (Braemer x Br 5509a), Sunshine (Br $6770 a 6$ $x$ Braemer), Francin (ST 3578/04 x Sebastian), Laudis 550 (Bojos x Sebastian), Bojos (Madonna x Nordus), Malz (Famin $x$ Scarlett)

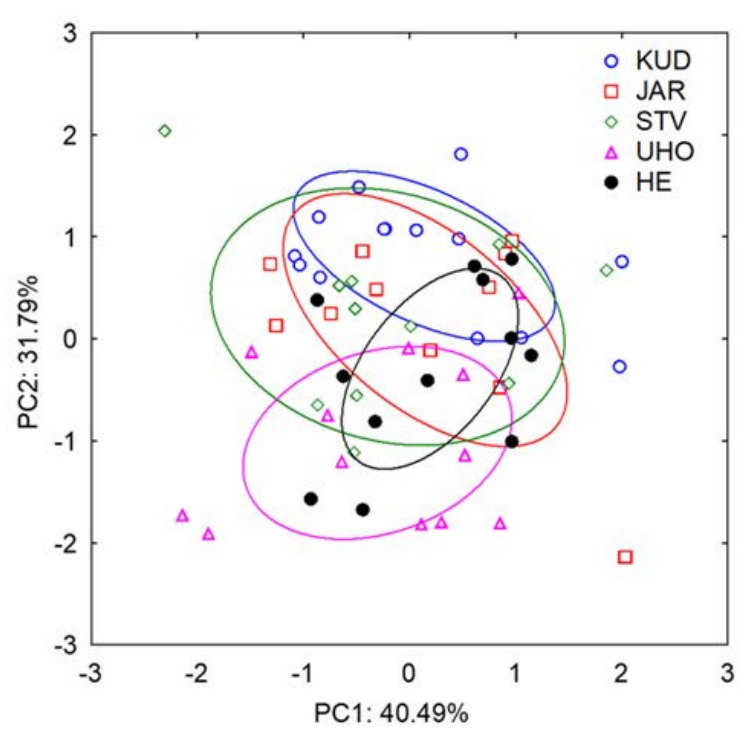

Figure 3 Principal component analysis score plot. The influence of barley variety from different growing locations on $F A$ profile

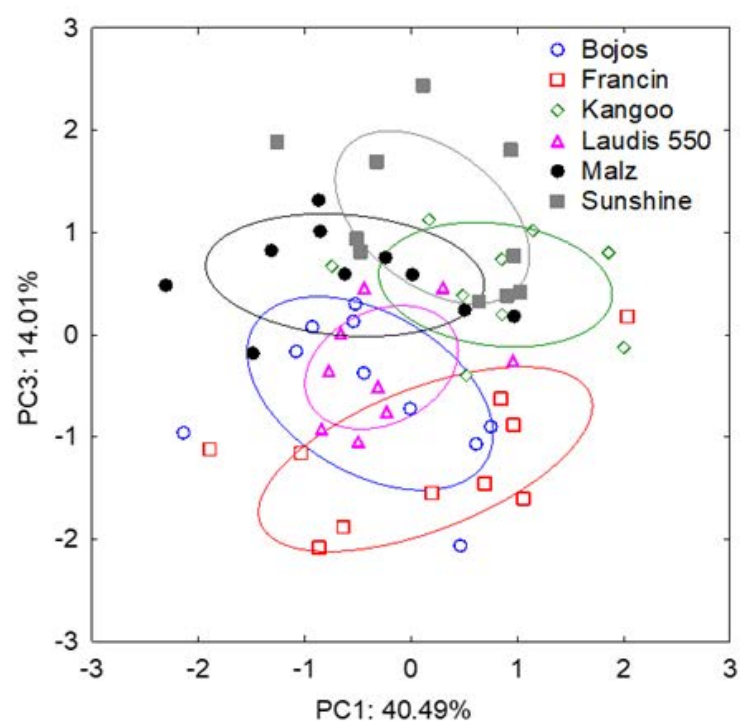

Figure 5 Principal component analysis score plot. The influence of barley variety on FA profile 
To sum up, due to a high level of crossbreeding of barley varieties, the profile of FA cannot be used as a tool for variety determination; however, it reflects the variety origin.

\subsection{Lipids and FA distribution during the malting process} In general, the decrease of lipids during a malting process was observed and ranged from 5 to $24 \%$. No statistical dependence on variety and geographical origin was found after malting. Bravi et al. reported a loss of total lipids ranging from 9 to 19\% (Bravi et al., 2012). The authors also divided varieties of tested barley samples into two groups based on the total lipid content. This distribution remained the same after malting. The findings are in contrast to our findings, because after malting we did not observe any dependences among the studied parameters. It should be noted that the compared experiments were conducted in a different way. We used 60 barley and related malt samples ( 6 varieties per 5 localities within 2 years); Bravi et al. analysed 15 barley and related malt samples ( 3 batches per 5 varieties, 1 location within 1 year). It could be the reason why we reached a rather different conclusion.

Finally, a distribution of individual FA during the malting process was evaluated. Mostly, no significant trend was found except for palmitic, oleic and alpha-linolenic (ALA) acids; the trends were compared to available data published previously. While the concentration of palmitic and oleic acids decreased during the malting process in our study and those of Bravi et al. (2012), Kaukovirta-Norja et al. (1993) and Anness (1984), the distribution of ALA in these studies varied. Further, Kaukovirta-Norja et al. observed no trend of ALA during malting (about 1500$1600 \mathrm{~g} \mathrm{~kg}^{-1}$ ) (Kaukovirta-Norja et al., 1993), while Anness found a decrease of ALA from 3120 to $2650 \mathrm{mg} \mathrm{kg}^{-1}$ and from 3030 to $2040 \mathrm{mg} \mathrm{kg}^{-1}$. However, the relative content remains the same (Anness, 1984). Bravi also described a reduction of ALA, from 1471-1736 mg kg-1 to $1233-1625 \mathrm{mg} \mathrm{kg}^{-1}$. When the relative content of ALA is considered, about a half of the samples have shown an increase and a half evinced decrease. By contrast, in our study we determined a significant increase of ALA concentration during malting, namely from $580-791 \mathrm{mg} \mathrm{kg}^{-1}$ to 853-1124 $\mathrm{mg} \mathrm{kg}^{-1}$. Since we did not find any statistically important dependence of ALA amount on barley variety, it could be assumed that the origin of this FA is influenced by malting conditions. This finding is worth noting because ALA (18:3n-3) is a polyunsaturated FA (PUFA) abundant in some vegetable oils; it is an essential precursor of the longer chain n-3 PUFA (commonly known as omega-3 fatty acids) and generally essential FA for mammals (Barceló-Coblijn et al., 2009). The first study of importance of ALA in human diet was published in the early 1980s (Holman et al., 1982; Holman, 1998). According to our information no detailed study about an origin of ALA during the malting process has as yet been available. Unfortunately, we are not able to explain the differences in ALA behaviour during the malting process found in these studies because we do not have detailed information about the tested grain and malting parameters.

\section{CONCLUSIONS}

It can be concluded that the FA content in barley grains is influenced by the land type, altitude and an average temperature in the growing location. The weak dependence on the barley variety is probably caused by a high level of crossbreeding. It is interesting that the differences observed among varieties are caused by minor FA (namely, lauric, arachidonic, pentadecanoic, palmitoleic and myristic acids), whereas the most abundant FA are varietally independent.

Further, the total content of lipids and also FA rather decreases during the malting process. It is probably caused either by a contribution of lipids during the germination or by the removal of acrospires.

\section{Acknowledgements}

This study was supported by the Ministry of Education, Youth and Sports of the Czech Republic No. LO 1312.

\section{References}

Aliferis, K.A., Cubeta, M.A., Jabaji, S. (2013). Chemotaxonomy of fungi in the Rhizoctonia solani species complex performing GC/MS metabolite profiling. Metabolomics 9(1), 159-169. https://doi. org/10.1021/jf101029a

Analytica EBC (2012). EBC Analysis Commitee-Nürnberg: Hans Carl Getränke-Fachverlag.

Anness, B.J. (1984). Lipids of barley, malt and adjuncts. J. Inst. Brew., 90(5), 315-318. https://doi.org/10.1002/j.2050-0416.1984.tb04282.x

Armanino, C., De Acutis, R., \& Festa, M.R. (2002). Wheat lipids to discriminate species, varieties, geographical origins and crop years. Anal. Chim. Acta, 454(2), 315-326. https://doi.org/10.1016/S00032670(01)01548-3

Barceló-Coblijn, G., \& Murphy, E.J. (2009). Alpha-linolenic acid and its conversion to longer chain n-3 fatty acids: Benefits for human health and a role in maintaining tissue n-3 fatty acid levels. Prog. Lipid Res., 48(6), 355-374. https://doi.org/10.1016/j.plipres.2009.07.002

Bravi, E., Marconi, O., Perretti, G., \& Fantozzi, P. (2012). Influence of barley variety and malting process on lipid content of malt. Food Chem., 135(3), 1112-1117. https://doi.org/10.1016/j.foodchem.2012.06.041

Brondz, I. (2002). Development of fatty acid analysis by high-performance liquid chromatography, gas chromatography, and related techniques. 
Anal. Chim. Acta 465(1-2), 1-37. https://doi.org/10.1016/S00032670(01)01467-2

Brondz, I., Olsen, I. (1990). Multivariate analyses of cellular carbohydrates and fatty acids of Candida albicans, Torulopsis glabrata, and Saccharomyces cerevisiae. J. Clinical Microbiol. 28(8), 1854-1857.

Doğru-Koca, A., Özcan, T., \& Yildirimli, Ş. (2016). Chemotaxonomic perspectives of the Paracaryum (Cynoglosseae, Boraginaceae) taxa based on fruit fatty acid composition. Phytochemistry 131, 100-106. https://doi.org/10.1016/j.phytochem.2016.08.012

Gangopadhyay, N., Rai D.K., Brunton N.P., Gallagher E., Harrison S.M. (2017). Fatty acids, sterols and tocols in Irish barley varieties: Profiling and correlation analysis. Eur. J. Lipid Sci. Technol., 119(4), 1600213-1600217. https://doi.org/10.1002/ejlt.201600213

García-Villalba, R., Cortacero-Ramírez, S., Segura-Carretero, A., \& Fernández-Gutiérrez, A. (2006). Free-zone capillary electrophoresis analysis of hordein patterns at different stages of barley malting. J. Agric. Food Chem. 54(18), 6713-6718. https://doi.org/10.1021/ jf060955m

Holman, R.T., Johnson, S.B., \& Hatch, T.F. (1982). A case of human linolenic acid deficiency involving neurological abnormalities. Am. J. Clin. Nutr., 35(3), 617-623. https://doi.org/10.1093/ajcn/35.3.617

Holman, R.T. (1998). The slow discovery of the importance of omega 3 essential fatty acids in human health. J. Nutr. 128(2), 427S-433S. https://doi.org/10.1093/jn/128.2.427S

Kaukovirta-Norja, A., Laakso, S., Reinikainen, P., \& Olkku, J. (1993). Lipolytic and oxidative changes of barley lipids during malting and mashing. J. Inst. Brew. 99(5), 395-403. https://doi. org/10.1002/j.2050-0416.1993.tb01179.x

Laštovičková, M., \& Bobálová, J. (2012). MS based proteomic approaches for analysis of barley malt. J. Cereal Sci., 56(3), 519-530. https://doi. org/10.1016/j.jcs.2012.07.013

Liu, K. (2011). Comparison of lipid content and fatty acid composition and their distribution within seeds of 5 small grain species. J. Food Sci., 76(2), C334-C342. https://doi.org/10.1111/j.17503841.2010.02038.x

Lopes, A.R., Baptista, M., Dionísio, G., Rosa, I., Paula, J.R., Gomes-Pereira, J., Figueiredo, C., Bandarra, N., Calado, R., \& Rosa, R. (2016). “Gone with the wind": Fatty acid biomarkers and chemotaxonomy of stranded pleustonic hydrozoans (Velella velella and Physalia physalis). Biochem. Systematic and Ecology 66, 297-306. https://doi. org/10.3389/fphys.2018.01675
MEBAK, 2011: Raw materials. Freising-Weihenstephan, Germany, 76-78. Pastor, K.A., Ačanski, M.M, Vujić, D.N., Kondić-Špika, A.Đ., \& Hristov, N.S. (2015). Lipid and sugar profiles of various barley cultivars (Hordeum vulgare). Acta Period. Technol., 46, 65-75. https://doi.org/10.2298/ APT1546065P

Psota, V., Jurečka, D., \& Horáková, V. (2005). Barley varieties registered in the Czech Republic in 2005. Kvasný průmysl, 51(6), 190-194. https://doi.org/10.18832/kp2005010

Psota, V., Horáková, V., \& Kopřiva, R. (2008). Barley varieties registered in the Czech Republic in 2008. Kvasný průmysl, 54(6), 186-192. https://doi.org/10.18832/kp2008012

Psota, V., Dvořáčková, O., \& Sachambula, L. (2012). Barley varieties registered in the Czech Republic in 2012. Kvasný průmysl, 58(5), 133139. https://doi.org/10.18832/kp2012013

Psota, V., Dvořáčková, O., \& Sachambula, L. (2013). Barley varieties registered in the Czech Republic in 2013. Kvasný průmysl., 59(5), 118126. https://doi.org/10.18832/kp2013012

Psota, V., Dvořáčková, O., Sachambula, L., \& Nečas, M. (2014). Barley varieties registered in the Czech Republic in 2014. Kvasný průmysl, 60(5), 114-122. https://doi.org/10.18832/kp2014011

Sahu, A., Pancha, I., Jain, D., Paliwal, C., Ghosh, T., Patidar, S., Bhattacharya, S., \& Mishra S. (2013). Fatty acids as biomarkers of microalgae. Phytochemistry 89, 53-58. https://doi.org/10.1016/j.phytochem.2013.02.001.

Řehulka, P., Allmaier, G., \& Chmelík, J. (2006). Využití nespecifických peptidů pro proteomickou identifikaci nízkomolekulárních proteinů z ječmene MALDI-TOF hmotnostní spektrometrií. Chem. Listy, 100(12), 1111-1115.

Svoboda, Z., Mikulíková, R., Běláková, S., Benešová, K., \& Nesvadba, Z. (2009). Determination of lipid content and fatty acid representation in barley caryopses and malt. Kvasný průmysl, 55(11-12), 315-320. https://doi.org/10.18832/kp2009026

Zhang, X.X., Zhang, Y.L., Niu, L.X., Sun, J.Y., Li, L.H., Znang, J., \& Li, J. (2017). Chemometric classification of different tree peony species native to China based on the assessment of major fatty acids of seed oil and phenotypic characteristics of the seeds. Chemical \& Biodiversity 14(1), e1600111. https://doi.org/10.1002/cbdv.201600111. 